\title{
11. MESOZOIC AND CENOZOIC MASS-ACCUMULATION RATES OF THE MAJOR SEDIMENT COMPONENTS IN THE NAURU BASIN, WESTERN EQUATORIAL PACIFIC ${ }^{1}$
}

\author{
David K. Rea, Oceanography Program, Department of Atmospheric and Oceanic Science, \\ The University of Michigan, Ann Arbor, Michigan \\ and \\ Jørn Thiede, Department of Geology, University of Oslo, Blindern, Oslo 3, Norway
}

\begin{abstract}
A 560-meter-thick sequence of Cenomanian through Pleistocene sediments cored at DSDP Site 462 in the Nauru Basin overlies a 500-meter-thick complex unit of altered basalt flows, diabase sills, and thin intercalated volcaniclastic sediments. The Upper Cretaceous and Cenozoic sediments contain a high proportion of calcareous fossils, although the site has apparently been below the calcite compensation depth (CCD) from the late Mesozoic to the Pleistocene. This fact and the contemporaneous fluctuations of the calcite and opal accumulation rates suggest an irregular influx of displaced pelagic sediments from the shallow margins of the basin to its center, resulting in unusually high overall sedimentation rates for such a deep $(5190 \mathrm{~m})$ site. Shallow-water benthic fossils and planktonic foraminifers both occur as reworked materials, but usually are not found in the same intervals of the sediment section. We interpret this as recording separate erosional interludes in the shallow-water and intermediate-water regimes. Lower and upper Cenozoic hiatuses also are believed to have resulted from mid-water events. High accumulation rates of volcanogenic material during Santonian time suggest a corresponding significant volcanic episode. The coincidence of increased carbonate accumulation rates during the Campanian and displacement of shallow-water fossils during the late Campanian-early Maestrichtian with the volcanic event implies that this early event resulted in formation of the island chains around the Nauru Basin, which then served as platforms for initial carbonate deposition.
\end{abstract}

\section{INTRODUCTION}

\section{DSDP Site 462}

Site 462 of the Deep Sea Drilling Project lies beneath 5190 meters of water in the northern portion of the Nauru Basin, at $7^{\circ} 14.25^{\prime} \mathrm{N}, 165^{\circ} 01.83^{\prime} \mathrm{E}$ (Fig. 1). The Nauru Basin is elongated in a north-northwest direction and bordered on all sides by topographic highs: the Marshall and Gilbert islands to the north, east, and southeast, the Caroline Islands to the northwest, and the Ontong-Java and Fiji plateaus to the west, southwest, and south. Depths are greatest in the northern part of the basin, where they exceed 5000 meters. Four major lithologic units comprise the 617 meters of sediment and rock cored at Site 462: Unit 1 is 297 meters of calcareous and radiolarian ooze with occasional volcanic ash and is Pleistocene to lower Oligocene; Unit 2 consists of moderately indurated sediments, cherts, chalks, and limestones, from 297 to 447 meters sub-bottom, which range back to the middle Maestrichtian; Unit 3, from 447 to 560 meters, is made up of volcaniclastic Maestrichtian to Campanian sediments and limestones; Unit 4 contains more volcaniclastic material and basaltic sills, beginning at 568 meters and continuing to 617 meters at the bottom of Hole 462 . Throughout the section, reworked pelagic and shallow-water reef and benthic materials occur. Hiatuses occurred during Pliocene to latest Miocene time (2.0 to $6.5 \mathrm{~m}$.y. ago), late to middle Miocene time (9.2 to 12 m.y. ago), middle to early

\footnotetext{
${ }^{1}$ Initial Reports of the Deep Sea Drilling Project, Volume 61.
}

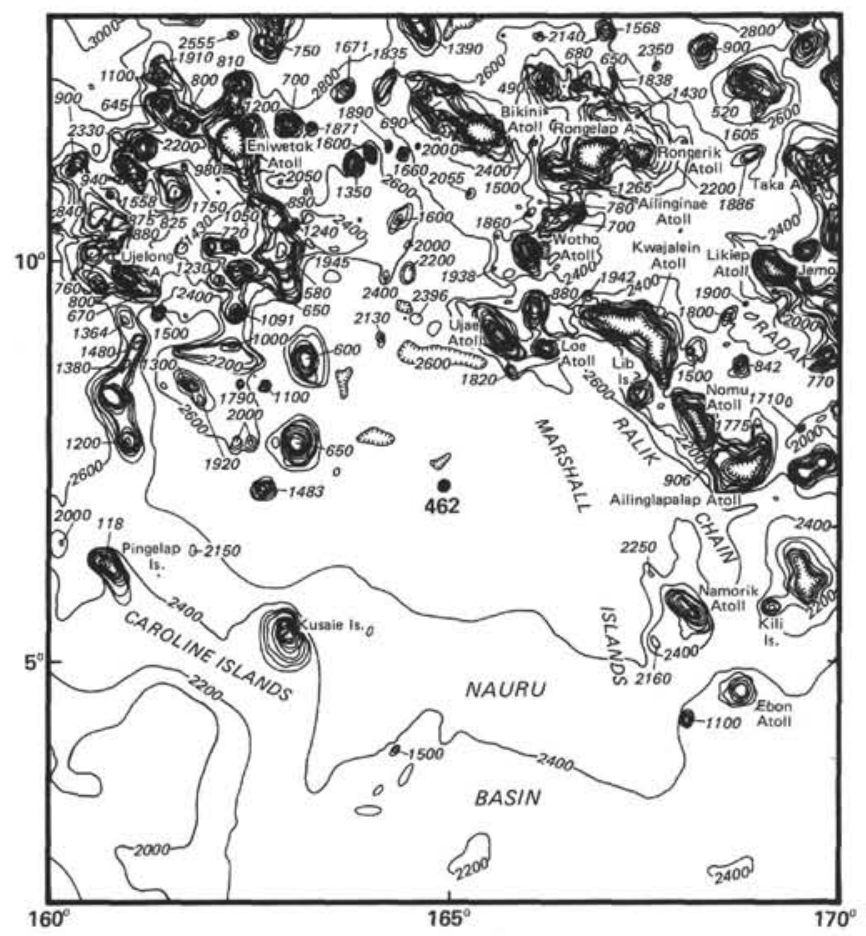

Figure 1. Bathymetric map of the Nauru Basin, showing location of DSDP Site 462 .

Miocene time (14.5 to 19 m.y. ago), and during late Paleocene time ( 53.5 to 59 m.y. ago). There may have been a hiatus during middle and late Eocene time ( 38 to 46 m.y. ago). Hole $462 \mathrm{~A}$, situated 476 meters NNE of 
Hole 462, penetrated the same section and an additional 450 meters of basalt with occasional sediment interlayers.

\section{Objectives}

The Nauru Basin drilling site was chosen in hopes of reaching Upper Jurassic oceanic crust and sampling Upper Jurassic sediments. Unfortunately, these hopes were not fulfilled, and the oldest sediments sampled occur in Hole $462 \mathrm{~A}$ below, 428 meters of nearly continuous diabase, and are Hauterivian, roughly 120 m.y. old. This, then, is the minimum age for the ocean floor in the northern Nauru Basin. We have backtracked this site along the appropriate age-depth curve, assuming a Hauterivian basement, allowing for loading by overburden, to determine when Site 462 may last have been above the calcite compensation depth (CCD). Results of this exercise reveal that Site 462 has been below the CCD, assumed to be about 3500 meters during the late Mesozoic (van Andel, 1975; Sclater et al., 1977), for at least 100 m.y.

Site 462 is of sedimentological interest because (1) it is situated in an old and previously undrilled basin of the western equatorial Pacific, and (2) it has accumulated a moderately thick section of carbonate sediments while lying below the CCD for essentially all its history. This second observation, in conjunction with the large amount of reworked shallow-water and pelagic material present, implies that much of the sediment has been subject to downslope displacement from the surrounding islands, seamounts, and plateaus. The history of carbonate input, then, should record episodes of winnowing and transport rather than surface-water productivity or deep-water dissolution.

Our objective in this study is to utilize the shipboard data from Site 462 to calculate the approximate mass accumulation rates through time of the major sedimentary components: calcareous material, pelagic siliceous material, and volcanogenic material, including the "pelagic" clays. From these values, we can determine the time of maximum, normal, and low or no input of the three components. Finally, we will interpret these fluctuating values in terms of the sedimentary, oceanographic, and volcanic history of the Nauru Basin.

\section{METHODS}

\section{Definition of Terms}

The rate at which sediment collects on the substrate can be determined in two different ways. The most common method is to divide a measured length of section by the time required for it to accumulate. This gives a value of length per unit time, commonly centimeters per thousand years, and is termed the linear sedimentation rate (LSR). Lower portions of sedimentary sections undergo compaction through time, with concomitant reduction in porosity to one half or one third of the initial values. Because of this compaction, linear sedimentation rates of near-surface and buried materials cannot be compared directly; older LSRs appear to be reduced in value (van Andel et al., 1975).

Another drawback of using LSR to describe sediment accumulation is that it is not a useful quantitative value in terms of exactly what and how much has been incorporated into the stratigraphic column. The relatively recent interest of low-temperature geochemists in sedimentology has illustrated the importance of quantifying the actual mass flux through the sediment/water interface. If such a flux can be calculated, it makes possible comparison of sediment input on both an areal and a temporal basis; such a value would not be affected by changes in porosity or compaction. This flux value is called the mass accumulation rate (MAR), and is a measure of just the dry mass of sedimentary material accumulating; its units are mass per unit area and unit time (commonly: $\mathrm{g} \mathrm{cm}^{-2} 10^{-3} \mathrm{year}^{-1}$ ) (van Andel et al., 1975). The MAR is a more difficult number to arrive at than the LSR because it involves measuring or calculating the dry bulk density, the dry weight of sediment per unit wet or initial volume. Mass accumulation rate is the product of the LSR and the dry bulk density:

$$
\frac{\mathrm{cm}}{10^{3} \text { years }} \times \frac{\mathrm{g}}{\mathrm{cm}^{3}}=\frac{\mathrm{g}}{\mathrm{cm}^{2} \cdot 10^{3} \text { years }},
$$

and is a quantitative measure of the rate at which material is added to the sediment. Furthermore, when the weight percentage of some sedimentary component is known, the product MAR $\times$ wt. $\%$ of component gives the mass accumulation rate of that particular fraction of the total sediment.

\section{Determination of Approximate MARs at Site 462}

We calculated the MAR of the three major sedimentary components present at Site 462 for every two-million-year interval represented throughout the core. To achieve this, it is necessary to know, for each interval, the LSR, dry bulk density, and percentage of each component. The linear sedimentation rate was calculated by combining the sediment ages from the planktonic microfossil zonations and appropriate time scales (Berggren, 1972; Berggren and van Couvering, 1974; van Hinte, 1976; and Hardenbol and Berggren, 1978) with the length of the cored interval, interpolating when necessary. Results of these calculations (Table 1 and Fig. 2) show the fluctuating LSR, 0.0 to $3.0 \mathrm{~cm} / 10^{3} \mathrm{y}$, for the sediments of Site 462 , not yet subdivided into $2-\mathrm{m} . \mathrm{y}$. divisions.

To calculate the approximate mass accumulation rates, the sediments were first divided into a series of units each representing an approximately 2-m.y. time span. Each interval was assigned an LSR, often the same as that given in Table 1, but occasionally interpolated across changes in sedimentation rate. To obtain the dry bulk density of each 2-m.y. lithologic interval, we first determined the average wet bulk density (WBD) from the GRAPE (Gamma Ray Attenuation Porosity Evaluator) data and gravimetrically determined onboard values (Boyce, this volume). These values were then converted first to porosity and subsequently to dry bulk density (DBD) by assuming a density of $1.03 \mathrm{~g} \mathrm{~cm}^{-3}$ for seawater and of $2.65 \mathrm{~g} \mathrm{~cm}^{-3}$ for the sediment grains. The final conversion factor turned out to be $\mathrm{DBD}=$ $1.636 \times$ WBD -1.685 . Finally, for each 2 -m.y. interval, we determined the sedimentary composition by averaging the onboard smearslide descriptions of dominant lithologies. Usually there were several descriptions per 2-m.y. interval, but a few intervals had only one. Table 2 is a compilation of all this information, for every time interval represented, and the calculated mass accumulation rates of the calcareous, planktonic opaline, and volcanogenic components of the sediment. These accumulation rates are plotted on Figure 3. The total MAR (Table 1) is plotted on Figure 2 to facilitate comparison with the LSR through time at Site 462.

The accuracy of all this information is difficult to determine. LSR values are controlled by the time-scale accuracy and our linear interpolation between zonal boundaries. Van Andel et al. (1975) estimated time-scale uncertainties to range from $\pm 1 \mathrm{~m} . \mathrm{y}$. at $10 \mathrm{~m} . \mathrm{y}$. to $\pm 5 \mathrm{~m} . \mathrm{y}$. at $100 \mathrm{~m} . \mathrm{y}$. in a logarithmic manner. We believe that our estimates of the two-million-year intervals are reasonable, although they depend, in turn, upon the lengths of the various zones used to date the sediments. Absolute ages of the 2 -m.y. intervals may deviate somewhat from the given value. The chronostratigraphic names will not vary, however, because they are tied to the same numerical time scales as our inferred sediment ages. The various density data have an accuracy of 0.01 to $0.04 \mathrm{~g} / \mathrm{cm}^{3}$ (Boyce, this volume), and therefore are not a source of significant error. Many of the inaccuracies present in Table 2 and Figure 3 result from our inability to determine accurately from smear slides the sediment composition in weight per cent. Percentages of components are estimated on the basis of area of the slide covered rather than on a weight per cent or volume basis. Calcareous materials and the finer sizes tend to be overestimated and 
Table 1. Shipboard data used to calculate linear sedimentation rates (LSR) and approximate mass accumulation rates (MAR) of the bulk sediment at Site 462 .

\begin{tabular}{|c|c|c|c|c|c|c|c|c|}
\hline $\begin{array}{l}\text { Core } \\
\text { Nos. }\end{array}$ & $\begin{array}{c}\text { Depth Sub-bottom } \\
\qquad Z(\mathrm{~m})\end{array}$ & $\begin{array}{c}\text { Cored } \\
\text { Interval, } \\
\triangle Z Z \\
\text { (m) }\end{array}$ & $\begin{array}{c}\text { Age of } \\
\text { Sediments, } \\
T \\
\text { (m.y.) }\end{array}$ & $\begin{array}{c}\text { Age Span } \\
\text { of Cores, } \\
\Delta T \\
\text { (m.y.) }\end{array}$ & $\begin{array}{c}\text { Linear } \\
\text { Sed. Rate, } \\
\text { LSR } \\
\text { (m/m.y.) }\end{array}$ & $\begin{array}{c}\text { Wet Bulk } \\
\text { Density, } \\
\text { WBD } \\
\left(\mathrm{g} / \mathrm{cm}^{3}\right)\end{array}$ & $\begin{array}{l}\text { Dry Bulk } \\
\text { Density, } \\
\text { DBD } \\
\left(\mathrm{g} / \mathrm{cm}^{3}\right)\end{array}$ & $\begin{array}{c}\text { Mass Accum. } \\
\text { Rate, } \\
\text { MAR } \\
\left(\mathrm{g} / \mathrm{cm}^{2} \bullet 10^{3} \text { years }\right)\end{array}$ \\
\hline $1-5$ & $0.0-48.0$ & 48.0 & $0.0-2.0$ & 2.0 & 24.0 & 1.26 & 0.38 & 0.91 \\
\hline $6-7$ & $48.0-67.0$ & 19.0 & $6.5-9.2$ & 2.7 & 7.0 & 1.52 & 0.80 & 0.56 \\
\hline $8-15$ & $67.0-143.0$ & 76.0 & $12-14.5$ & 2.5 & 30.4 & 1.50 & 0.77 & 2.34 \\
\hline $16-18$ & $143.0-171.5$ & 28.5 & $19-24$ & 5.0 & 5.7 & 1.56 & 0.87 & 0.50 \\
\hline $19-22$ & $171.5-209.5$ & 38.0 & $24-29$ & 5.0 & 7.6 & 1.58 & 0.90 & 0.68 \\
\hline $23-28$ & $209.5-266.5$ & 57.0 & $29-34.5$ & 5.5 & 10.4 & 1.65 & 1.01 & 1.05 \\
\hline $29-33$ & $266.5-314.0$ & 47.5 & $34.5-37$ & 2.5 & 19.0 & 1.63 & 0.98 & 1.86 \\
\hline $34-40$ & $314.0-380.5$ & 66.5 & $37-49$ & 12.0 & 5.5 & 1.67 & 1.05 & 0.58 \\
\hline $41-44$ & $380.5-418.5$ & 38.0 & $49-53.5$ & 4.5 & 8.4 & 2.30 & 2.08 & 1.76 \\
\hline $45-50$ & $418.5-475.5$ & 57.0 & $59-70$ & 11.0 & 5.2 & 1.98 & 1.55 & 0.81 \\
\hline $51-54$ & $475.5-513.5$ & 38.0 & $70-75$ & 5.0 & 7.6 & 2.02 & 1.62 & 1.23 \\
\hline $55-56$ & $513.5-531.5$ & 18.0 & $75-78$ & 3.0 & 6.0 & 1.89 & 1.41 & 0.85 \\
\hline $57-58$ & $531.5-549.5$ & 18.0 & $78-92$ & 14.0 & 1.3 & 1.82 & 1.29 & 0.17 \\
\hline $59-60$ & $549.5-567.5$ & 18.0 & $92-102.5$ & 10.5 & 1.7 & 1.84 & 1.33 & 0.23 \\
\hline
\end{tabular}
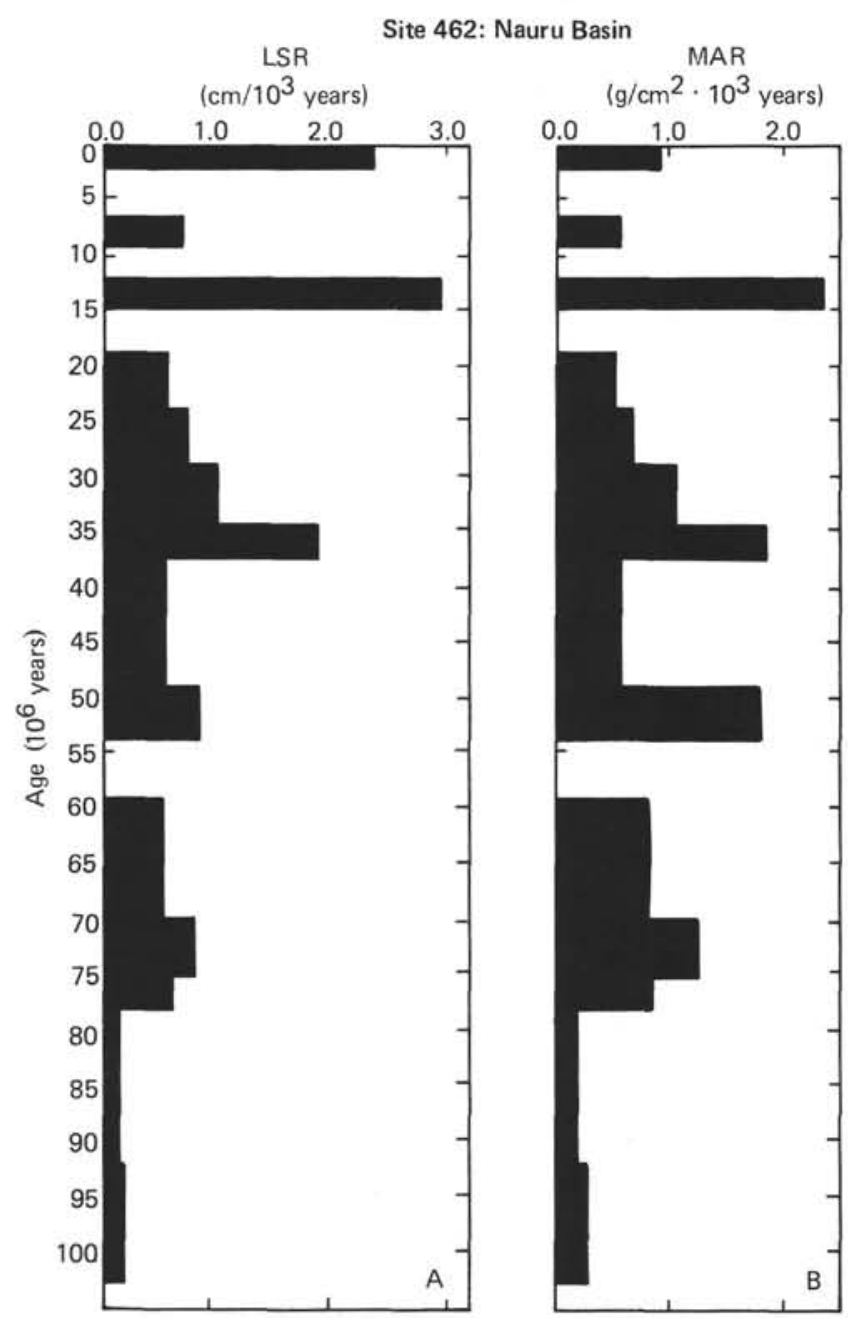

Figure 2. (A) Linear sedimentation rates (LSR) and (B) mass accumulation rates (MAR) calculated for the sediment cored in the Nauru Basin. These data are for the total sediment before the rates are broken down into 2-m.y. intervals.

volcanogenic materials and the coarser sizes underestimated. Further, every sedimentologist will estimate relative abundnces a bit differently. Moderate differences in composition, 10 to $20 \%$, therefore, are not likely to be meaningful.

As a result of all the inaccuracies inherent in the use of these types of data, fluctuations in the MARs that do not exceed a factor of 2 or
Table 2. Sediment accumulation data for Site 462 , subdivided into approximate 2-m.y. intervals (M.Y.I.).

\begin{tabular}{|c|c|c|c|c|c|c|c|c|c|}
\hline M.Y.I. & Core(s) & LSR & DBD & $\mathrm{CC}$ & OC & vC & CAR & OAR & VAR \\
\hline $0-2$ & $1-5$ & 2.40 & 0.38 & 47.8 & 29.8 & 18.1 & 0.44 & 0.27 & 0.17 \\
\hline $6.5-9.2$ & $6-7$ & 0.70 & 0.80 & 85.3 & 10.7 & 3.5 & 0.48 & 0.06 & 0.02 \\
\hline $12.0-14.5$ & $8-15$ & 3.04 & 0.77 & 67.3 & 23.5 & 7.5 & 1.58 & 0.55 & 0.18 \\
\hline $19-21$ & 16 & 0.57 & 0.87 & 69.2 & 9.2 & 16.9 & 0.34 & 0.05 & 0.08 \\
\hline $21-23$ & $17-18$ & 0.57 & 0.87 & 30.2 & 54.3 & 9.3 & 0.15 & 0.30 & 0.05 \\
\hline $23-25$ & $18-19$ & 0.66 & 0.89 & 57.0 & 40.0 & - & 0.33 & 0.23 & - \\
\hline $25-27$ & $19-20$ & 0.76 & 0.90 & 57.6 & 36.3 & 6.3 & 0.39 & 0.25 & 0.04 \\
\hline $27-29$ & $20-22$ & 0.76 & 0.90 & 54.4 & 29.8 & 13.5 & 0.37 & 0.20 & 0.09 \\
\hline $29-31$ & 23 & 1.04 & 1.01 & 92.0 & 3.0 & 1.0 & 0.97 & 0.03 & 0.01 \\
\hline $31-33$ & $23-26$ & 1.04 & 1.01 & 77.8 & 19.5 & 1.7 & 0.82 & 0.20 & 0.02 \\
\hline $33-35$ & $26-29$ & 1.25 & 1.00 & 78.7 & 17.3 & 3.1 & 0.98 & 0.22 & 0.04 \\
\hline $35-37$ & $29-33$ & 1.90 & 0.98 & 60.6 & 29.4 & 5.1 & 1.13 & 0.55 & 0.09 \\
\hline $37-39$ & $34-38$ & 0.55 & 1.05 & 54.3 & 40.4 & 3.6 & 0.31 & 0.23 & 0.02 \\
\hline $39-41$ & 39 & 0.55 & 1.05 & 36.2 & 48.8 & 10.0 & 0.21 & 0.28 & 0.06 \\
\hline $41-43$ & 39 & 0.55 & 1.05 & 36.2 & 48.8 & 10.0 & 0.21 & 0.28 & 0.06 \\
\hline $43-45$ & 39 & 0.55 & 1.05 & 36.2 & 48.8 & 10.0 & 0.21 & 0.28 & 0.06 \\
\hline $45-47$ & 39 & 0.55 & 1.05 & 36.2 & 48.8 & 10.0 & 0.21 & 0.28 & 0.06 \\
\hline $47-49$ & $39-40$ & 0.55 & 1.05 & 1.0 & 65.0 & 30.0 & 0.01 & 0.38 & 0.17 \\
\hline $49-51$ & $41-42$ & 0.84 & 2.08 & 15.0 & 58.5 & 15.0 & 0.26 & 1.02 & 0.26 \\
\hline $51-53.5$ & $43-44$ & 0.84 & 2.08 & 94.7 & 1.2 & 2.8 & 1.65 & 0.02 & 0.05 \\
\hline $59-61$ & $45-46$ & 0.52 & 1.55 & 91.0 & 2.0 & 7.0 & 0.73 & 0.02 & 0.06 \\
\hline $61-63$ & $45-46$ & 0.52 & 1.55 & 91.0 & 2.0 & 7.0 & 0.73 & 0.02 & 0.06 \\
\hline $63-65$ & $45-46$ & 0.52 & 1.55 & 91.0 & 2.0 & 7.0 & 0.73 & 0.02 & 0.06 \\
\hline $65-67$ & $45-46$ & 0.52 & 1.55 & 91.0 & 2.0 & 7.0 & 0.73 & 0.02 & 0.06 \\
\hline $67-69$ & $47-48$ & 0.52 & 1.55 & 87.7 & 3.3 & 8.7 & 0.71 & 0.03 & 0.07 \\
\hline $69-71$ & $49-52$ & 0.64 & 1.58 & 34.9 & tr & 62.1 & 0.35 & - & 0.63 \\
\hline $71-73$ & $52-54$ & 0.76 & 1.62 & 61.2 & - & 38.0 & 0.75 & - & 0.47 \\
\hline $73-75$ & 54 & 0.76 & 1.62 & 46.5 & 0.5 & 53.0 & 0.57 & 0.01 & 0.65 \\
\hline $75-77$ & 55 & 0.60 & 1.41 & 11.7 & - & 88.3 & 0.10 & - & 0.75 \\
\hline $77-79$ & $55-56$ & 0.36 & 1.36 & 21.3 & - & 78.2 & 0.10 & - & 0.38 \\
\hline $79-81$ & 57 & 0.13 & 1.29 & 9.6 & 0.2 & 90.0 & 0.02 & - & 0.15 \\
\hline $81-83$ & 57 & 0.13 & 1.29 & 9.6 & 0.2 & 90.0 & 0.02 & - & 0.15 \\
\hline $83-85$ & 57 & 0.13 & 1.29 & 9.6 & 0.2 & 90.0 & 0.02 & - & 0.15 \\
\hline $85-87$ & 58 & 0.13 & 1.29 & 23.3 & - & 76.7 & 0.04 & - & 0.13 \\
\hline $87-89$ & 58 & 0.13 & 1.29 & 23.3 & - & 76.7 & 0.04 & - & 0.13 \\
\hline $89-91$ & 58 & 0.13 & 1.29 & 23.3 & - & 76.7 & 0.04 & - & 0.13 \\
\hline $91-93$ & 59 & 0.15 & 1.31 & 3.6 & - & 96.4 & 0.01 & - & 0.19 \\
\hline $93-95$ & 59 & 0.17 & 1.33 & 3.6 & - & 96.4 & 0.01 & - & 0.22 \\
\hline $95-97$ & 59 & 0.17 & 1.33 & 3.6 & - & 96.4 & 0.01 & - & 0.22 \\
\hline $97-99$ & 60 & 0.17 & 1.33 & - & - & 100.0 & - & - & 0.23 \\
\hline 99-101 & 60 & 0.17 & 1.33 & - & - & 100.0 & - & - & 0.23 \\
\hline $101-102.5$ & 60 & 0.17 & 1.33 & - & - & 100.0 & - & - & 0.23 \\
\hline
\end{tabular}

Note: CC, OC, and VC are the concentrations of carbonate, opaline and volcanogenic material in smear slides representing that age interval. These values need not sum to $100 \%$, as other minor sedimentary components often occur. CAR, OAR, and VAR are the approximate mass accumulation rates of the three major components. Other column headings as in Table 1.

more cannot be assigned any geological significance. The data do show order-of-magnitude variations in the various accumulation rates that record real sedimentary events, and the ensuing discussion will concern those events.

\section{ACCUMULATION RATES}

The sedimentary column penetrated at Site 462 (Site Summary, this volume) is highly variable in composi- 


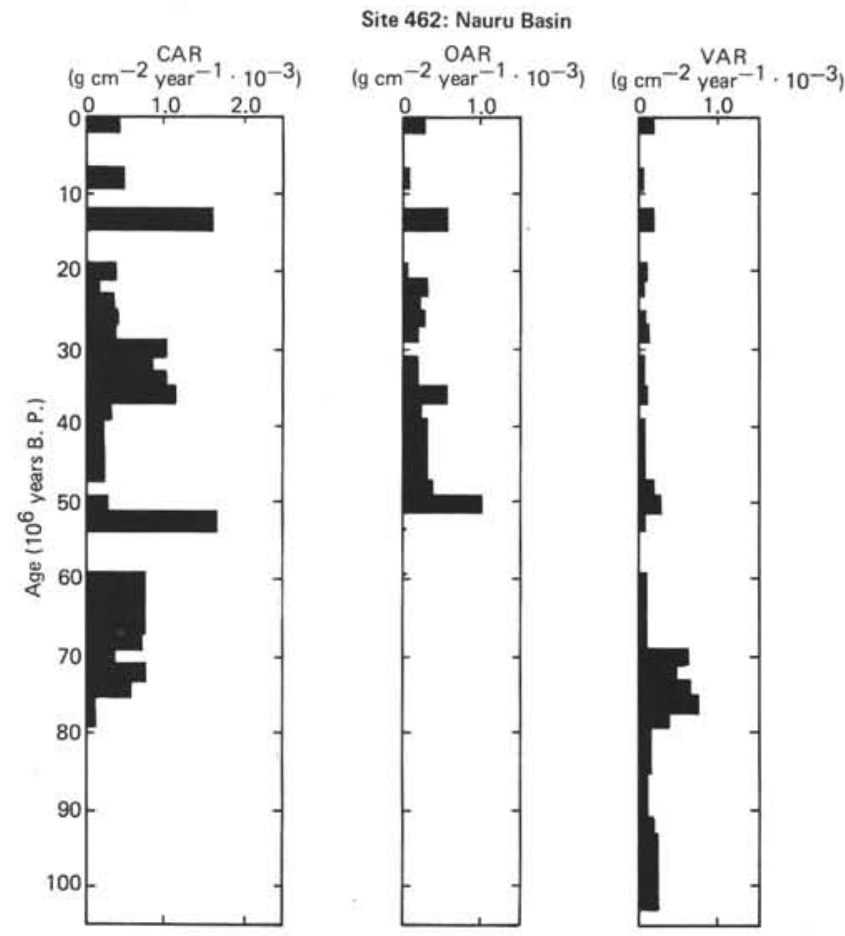

Figure 3. Approximate mass accumulation rates of the three major sedimentary components: carbonate accumulation rate (CAR); opal accumulation rate (OAR); volcanogenic accumulation rate (VAR).

tion. The deposits range from carbonate-rich to entirely carbonate-free sediments which are dominated by volcanogenic material. The varying abundances of these components, as well as of opaline planktonic fossils, suggest major temporal changes of the processes controlling the sediment flux to the central Nauru Basin during the last $95 \mathrm{~m} . \mathrm{y}$. The consequence of hiatuses during Paleocene and Miocene/Pliocene time (Fig. 2) is that only segments of the Cretaceous and Cenozoic depositional history of this portion of the western equatorial Pacific have been preserved.

The LSRs of the sedimentary section fluctuate over the wide range of from less than 0.2 to more than $3.0 \mathrm{~cm}$ $10^{-3}$ year $^{-1}$ (Fig. 2). Although we have tried to calculate LSRs for each 1- or 2-m.y. interval, the biostratigraphic control is in some parts so poor that we have no proof of continuous sedimentation during the periods believed to be represented by the cores obtained from this site. The very small LSRs during the mid-Cretaceous and several other intervals suggest the presence of additional diastems. The mass accumulation rates of the calcareous, opaline, and volcanogenic material deposited at Site 462 (Fig. 3, Table 2) span one to two orders of magnitude (Fig. 3). They also vary at least in part independently of each other, suggesting that these rates are not determined by the stratigraphic framework used to date these deposits.

\section{MARs of the Calcareous and Opaline Components}

Calcareous material, mostly pelagic and shallowwater benthic fossils (Premoli Silva, this volume), is a major sedimentary component at Site $\mathbf{4 6 2}$ throughout the post-mid-Cretaceous sediments, despite its position well below the upper Mesozoic and Cenozoic calcite compensation depth (van Andel, 1975; Berger et al., 1976; Sclater et al., 1977). These facts and the sedimentary structures at this site suggest that the entire volume of calcareous deposits found today in the deep parts of the Nauru Basin has been displaced from regions in and around the basin center that were shallower than the CCD. Pulses of particularly high flux $\left(>0.9 \mathrm{~g} \mathrm{~cm}^{-2}\right.$ $10^{-3}$ year $^{-1}$ ) of calcareous material evidently occurred $52,33-37,30$, and $13 \mathrm{~m} . y$. ago. The Oligocene maximum in carbonate accumulation followed immediately after a 1-km drop of the CCD at the end of Eocene time (van Andel, 1975), and apparently corresponded to a significant lowering of sea level that occurred during the Oligocene (Vail et al., 1977). During 1952, two holes were drilled to basaltic basement on Eniwetok Atoll in the Marshall Islands $\left(11.5^{\circ} \mathrm{N}, 162.3^{\circ} \mathrm{E}\right)$. The section recovered included shallow-water Eocene limestones overlying olivine basalt, no Oligocene materials, and a reasonably complete, shallow-water, Miocene to Recent sequence (Ladd et al., 1953). This Oligocene hiatus at Eniwetok coincided with the high influx to the Nauru Basin of carbonates containing shallow-water benthic fossils (Figs. 3 and 4), and supports the suggestion of erosion in shallow waters during that time.

Other maxima in carbonate accumulation appear to be unrelated to CCD fluctuations, but may correspond to erosion during relative lowerings in sea level (Vail et al., 1977). It is interesting that the two maxima (middle Miocene and early Eocene) in accumulation rates occurred just after two prominent, global-scale hiatuses (Moore et al., 1978) (Figs. 2 and 3). The passage of Site 462 beneath the equatorial high-productivity zone during Eocene time is not reflected by high carbonate accumulation rates.

The accumulation rates of planktonic opaline components generally follow those of calcareous material during the last 50 m.y. Before this time, the calculated values reveal a very low rate of opal accumulation in the Nauru Basin. However, the siliceous portion of the sediment has probably been concentrated by diagenesis into the hard chert layers, which are under-represented in these cores owing to poor recovery; smear-slide data also favor the softer portions of the sediments which are depleted of silica.

\section{MAR of Volcanogenic Components}

The mass accumulation of volcanogenic debris had moderate peaks during the Pleistocene, middle Miocene, and Eocene, and a broader maximum during Late Cretaceous time (Table 2; Fig. 3). Kennett et al. (1977) have documented significant maxima in volcanic extrusion rates around the Pacific rim that occurred during middle Miocene and Quaternary time. Other evidence from the Hawaiian chain suggests that maxima in midplate volcanism may coincide with those at plate margins (Rea and Scheidegger, 1979). The increased volcanic accumulation rates during these times, therefore, appear to have been part of a pan-Pacific phenomenon. 


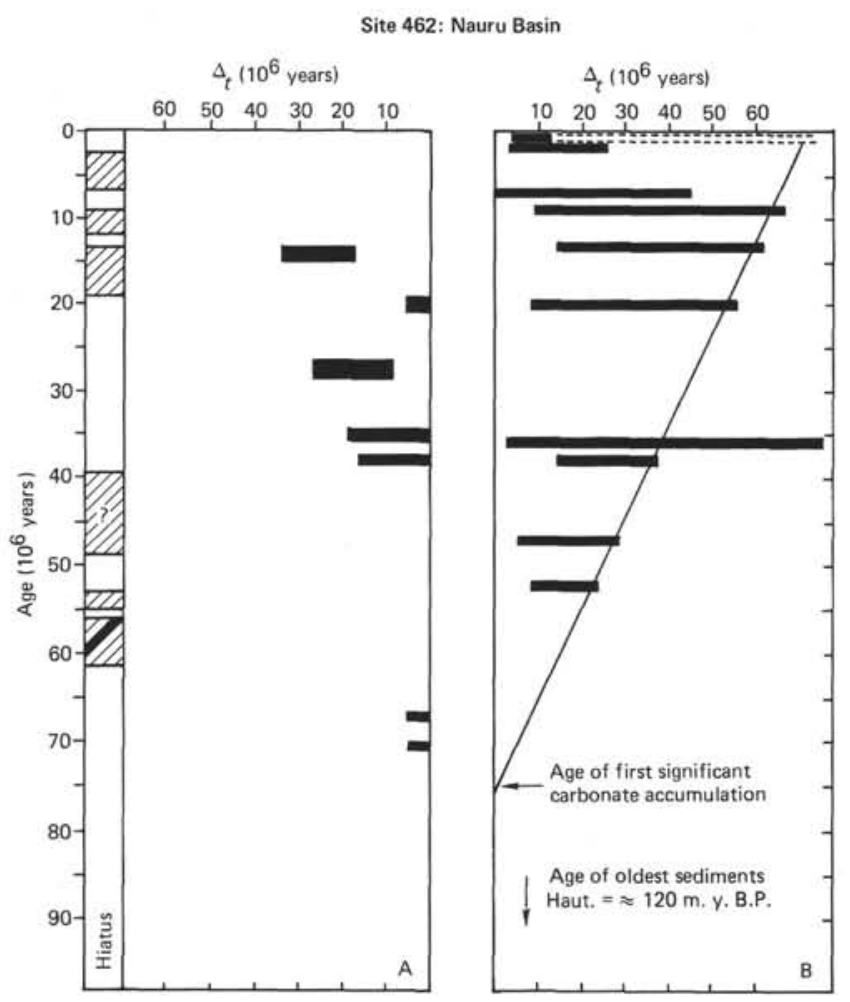

Figure 4. Relative ages of reworked and displaced fossils. $\Delta_{t}=$ age of reworked material minus age of host sediment. Bar length records age span of reworked material in reference to host material. (A) Shallow-water benthic fossils, generally coeval with host material. (B) Reworked pelagic material. Note gradual increase of $\Delta_{t \max }$, followed by sharp but regular decline in the Pleistocene. Lower Tertiary and Upper Cretaceous fossils found in Pleistocene sediments are extremely rare, and may be components which have been reworked several times. See text for discussion. After Premoli Silva and Brusa (this volume).

Another small increase in volcanism occurred during the early to middle Eocene; it is not clear whether this was the result of a regional, rim-of-the-Nauru-Basin, or ocean-wide event.

A significant increase in the MAR of volcanic debris is represented in the Upper Cretaceous between the lower Maestrichtian and the upper portion of the Santonian, spanning ages of about 69 to 79 m.y. (van Hinte, 1976). Cores from several DSDP sites in the central and western equatorial Pacific record increased accumulation of volcanic debris at about the same time, usually with maxima during Campanian to early mid-Maestrichtian time. These sites are located in the Caroline Islands (Site 199, Leg 20: Heezen, MacGregor, et al. 1973), in the Central Pacific Basin between the Marshalls and the Line Islands (Site 66, Leg 7: Winterer, Riedel, et al., 1971; Sites 166, 169, and 170, Leg 17: Winterer, Ewing et al., 1973), along the Line Islands chain (Site 165, Leg 17; Sites 315 and 316, Leg 33: Schlanger, Jackson, et al, 1976), and northeast of the Line Islands (Site 164, Leg 17). Most other DSDP holes in this general region did not penetrate through the ubiquitous Eocene cherts.
Authors of the several site reports (referenced above) all attributed the observed Cretaceous volcanic debris to the formation of the adjacent seamounts and islands. This 10- or 15-m.y. span in the Late Cretaceous, therefore, appears to have been the time of a significant volcanic event that resulted in the formation of the Caroline, Marshall, Gilbert, and Line islands. The more easterly-trending chains to the south, the Marquesas, Society, and Tauamotu islands, are younger features (Duncan and McDougal, 1974; Dalrymple, et al., 1975), and the Mid-Pacific Mountains to the north are older (Thiede, Vallier, et al., in preparation). The record of accumulation of Cretaceous volcanogenic sediments reveals a 30 - to $35-\mathrm{m} . \mathrm{y}$. history of activity, presumably associated with the construction of nearby seamounts and islands, since the cessation of ocean-floor basaltic volcanism in late Albian time. This accumulation continued at moderate rates until earliest Campanian, when it increased markedly; presumably, this increase marks the time of formation of the island chains around the Nauru Basin. The first major influx of carbonate sediments 75 m.y. ago occurred 4 m.y. after the dramatic increase in volcanic input (Fig. 3).

\section{CAUSES OF CHANGES IN SEDIMENT ACCUMULATION RATE}

The major portion of the calcareous and opaline components of Site 462 sediments are believed to represent displaced and reworked material because (1) the sedimentary structures in the cores from this site include lamination, cross lamination, graded bedding, and scour (Site Summary, this volume); (2) displaced shallow- and deep-water fossils have been found in certain stratigraphic intervals at Site 462 (Premoli Silva and Brusa, this volume); and (3) the central Nauru Basin floor subsided to water depths considerably below the estimated CCD by mid-Cretaceous time.

Diagnostic shallow-water fossils have been found in several intervals (Fig. 4). The two older horizons are embedded in upper Campanian to middle Maestrichtian sediments, and contain larger foraminifers, fragments of mollusks, bryozoan and echinoid remains, and red algae. The larger foraminifers belong to the genera Asterorbis, Pseudorbitoides, Sulcoperculina, and Vaughanina. The molluskan fossils include remains of rudists (?) and of Inoceramus. These sediment components are therefore believed to have been displaced from bank areas (perhaps from coastal regions of the islands surrounding the Nauru Basin) which were at or near sea level during Campanian-Maestrichtian time. The occurrence of Campanian-Maestrichtian shallow-water fossils apparently represents one or two relatively shortlived erosional events that resulted in displaced material and host sediment of essentially the same age.

This is not always the case in horizons with shallowwater fossils which occur in upper Eocene to mid-Miocene deposits. The oldest and one of the youngest intervals recording displacement (Fig. 4A) of shallow-water fossils are believed to contain reworked material contemporaneous with their host sediments. The upper Eo- 
cene horizon at $38 \mathrm{~m} . y$. B.P. contains a few larger foraminifers belonging to the genera Nummulites, Operculina, Assilina, Asterocyclina, and Miogypsinoides, which occur together with fragments of red algae. The lower Miocene displaced shallow-water components include larger foraminifers belonging to the genera $\mathrm{Am}$ phistegina, Heterostegina, Miogypsinoides, and Discocyclina, which were found together with bryozoan debris. The lower Miocene horizons with displaced shallowwater fossils have been generated by two events (Fig. $4 \mathrm{~A}$ ), the older one eroding several shallow-water deposits, the younger one eroding Eocene to lower Oligocene material. The Eocene and Miocene intervals bracket upper Oligocene deposits which contain a high proportion of displaced lower Eocene to (?) lower Oligocene shallow-water fossils (abundant larger foraminifers of the genera Alveolina, Asterocyclina, Assilina, Helycolepiclina, Heterostegina, Miogypsinoides, Nummulites, and Operculina, together with fragments of mollusks, corals, bryozoans, echinoids, and red algae). These horizons therefore represent erosion cutting into deposits 10 to $30 \mathrm{~m} . \mathrm{y}$. older than the host sediments. The Eniwetok borehole data, already discussed, also suggest more severe erosion during the Oligocene than during the rest of the Tertiary (Ladd et al., 1953). Shallow-water fossils originating from similar time-stratigraphic intervals have been detected in the equivalent MaestrichtianCampanian and Oligocene deposits of Site 165 near the Line Islands (Winterer, Ewing, et al., 1973).

Whereas neritic sediment components displaced into the deep ocean represent erosional events close to the sea surface, reworked pelagic sediment components document events in intermediate and deep water masses. Displaced planktonic foraminiferal shells found in Site 462 sediments (Premoli Silva and Brusa, this volume) must have been deposited originally at intermediate water depths above the upper Mesozoic and Cenozoic CCD at about 3500 meters depth (van Andel, 1975; Sclater et al., 1977).

It was possible to determine in detail the age distribution of the displaced faunal components because of the rapid evolution of the late Mesozoic and Cenozoic planktonic foraminifers. In Figure 4 we have tried to illustrate the age relationship between reworked and host materials by plotting the range of the minimum $\left(\Delta_{t} \min \right)$ and maximum $\left(\Delta_{t} \max \right)$ differences between the age of the reworked fossils and that of the corresponding host sediments. Five observations concerning the reworked material seem to be particularly important: (1) $\Delta_{t} \max$ (possibly also $\Delta_{t \mathrm{~min}}$ ) increased in a fairly regular fashion from early Tertiary to Pleistocene times; (2) both $\Delta_{t \text { max }}$ and $\Delta_{t \min }$ drop sharply but regularly in the youngest sediments; (3) the Paleocene and Miocene/Pliocene hiatuses are overlain by sediments of high accumulation rates, including displaced material with $\Delta_{t}$ values over reasonably wide time spans; (4) no displaced Early Cretaceous or Jurassic guide fossils have been found in these cores (except in Core 27, where Aptian-Albian planktonic foraminifers occur), despite the widespread occurrence of displaced material throughout almost the entire sediment section of Site 462; and (5) many of the intervals with reworked planktonic foraminifers contain also small benthic, calcareous bathyal to abyssal foraminifers.

Sediments cored at Site 165 close to the Line Islands also contained displaced pelagic fossils in the 20- to 35-m.y.-old part of the section (Winterer, Ewing, et al., 1973). These consisted of planktonic foraminiferal species in Oligocene and lower Miocene cores with $\Delta_{t}$ values comparable to the range of those observed at Site 462. The Site $165 \Delta_{t}$ values also increase with decreasing age throughout the interval where displaced pelagic fossils have been found. At both sites, the reworked sediment components of shallow-water and pelagic origin can occur together, but rather more frequently they occur in different parts of the sediment section. They may therefore represent erosional events of different types.

The $\Delta_{t \text { max }}$ of the displaced pelagic fossils would be expected to increase in a fairly regular fashion in a dynamic depositional environment where deposition in general exceeds erosion, but where a sedimentary section of increasing age differential (age of eroded material - age of deposition, $\Delta_{t}$ ) is available for erosion. This trend also means that in the source area of the displaced components erosion generally exceeds deposition as the older sediments remain accessible to erosion for some length of time. Major deviations from the trend documented in Figure 4 occur after severe disturbances of the dynamic balance between deposition and erosion. At Site 462 , such disturbances are marked by the major hiatuses which are overlain by sediments with high MARs (Fig. 2). The $\Delta_{t \max }$ above the Eocene hiatus increases rapidly to more than $70 \mathrm{~m} . \mathrm{y}$. because this erosional event affected Aptian-Albian deposits which both before and after this event apparently were protected against reworking.

The reworked pelagic fossils which have been found incorporated into the thick Pleistocene section at Site 462 show the reverse trend with $\Delta_{t}$ values decreasing sharply with decreasing sediment age, if rare specimens of older faunas mixed into the younger reworked fossil assemblages are discounted (Fig. 4). This trend of ever younger reworked material strongly implies that, within its source area, the outcrops of older sediment have been rendered unavailable for erosion before those of more recent sediments. Such a scenario seems plausible when one realizes that, as a result of subsidence through the $C C D$, a seamount will have exposed older material lower on its flanks while the upper portion will be covered with ever younger material; other things being equal, the map-view outcrop pattern on a conical seamount will resemble a bullseye, with an old rim and a young center. Pleistocene sediment in the Nauru Basin is about $60 \%$ calcareous material and has, like the rest of the section, been emplaced in part by downslope transport off the supra-CCD topographic highs, filling the lower regions, and possibly in part by pelagic deposition above a depressed CCD during glacial times. Presently, the CCD is at 4700 to 4800 meters in the Nauru Basin (Berger et al., 1976). This rapid basin fill- 
ing $(43 \mathrm{~m} / \mathrm{m} . \mathrm{y}$.) appears to have quickly covered the older outcrops and protected the newly buried sediment from further reworking.

Data from the Nauru Basin present one of the first instances where we can separate past erosional events brought on by surface-water activity (resulting in reworked shallow-water benthic foraminifers and other shallow-water fossils, Fig. 4A) from those caused by intermediate-depth phenomena (pelagic realm but above the CCD, Fig. 4B). Apparently the two events need not occur simultaneously; either can happen alone (compare Figs. 4A and 4B).

The Eocene and lower to middle Miocene hiatuses in the Nauru Basin are isochronous with gaps in sedimentation mapped, from DSDP data, across much of the world's oceans (van Andel et al., 1975; Moore et al., 1978). These hiatuses have been attributed to increased vigor of bottom-water circulation, in conjunction with the opening of the Antarctic-Australian passage in the Eocene or the onset of glaciation in Antarctica during the Miocene (van Andel et al., 1975). The Nauru Basin, however, has probably been isolated from direct input of northward-flowing bottom water ever since its rim of peripheral highs was completed by the Late Cretaceous volcanic event. Sill depth is now about 4500 to 4600 meters through some fairly small passages to the northwest and east. Changes in bottom-water circulation, therefore, may not have had any effect on Nauru sedimentation since the Late Cretaceous; sediment hiatuses would have resulted from variations in the mid-water regime. Information from other similar depositional basins would be required to determine whether the midwater events recorded in the Nauru Basin were the result of merely local or regional activity or whether the deepwater events recorded in many places (van Andel et al., 1975; Moore et al., 1978) involved the entire water column and thus affected deposition at all depths.

\section{ACKNOWLEDGMENTS}

We would like to thank the Deep Sea Drilling Project for allowing us to participate in Leg 61, and the Co-Chief Scientists, Sy Schlanger and Roger Larson, who shared with us their knowledge of the regional geology. Isabella Premoli-Silva and Bill Sliter kindly provided to us their information about the reworked fossil materials. Ms. C. Deen was kind enough to type the first comprehensible version of the manuscript. Isabella Premoli Silva, C. G. Adelseck, and W. E. Dean reviewed this manuscript, and we appreciate their comments and suggestions.

\section{REFERENCES}

Berger, W. H., Adelseck, C. G., Jr., and Mayer , L. A., 1976. Distribution of carbonate in surface sediments of the Pacific Ocean. $J$. Geophys. Res., 81:2617-2627.
Berggren, W. A., 1972. A Cenozoic time-scale: Some implications for regional geology and paleobiogeography. Lethaia, 5:195-215.

Berggren, W. A., and Van Couvering, J. A., 1974. The late Neogene biostratigraphy, geochronology and paleoclimatology of the last 15 million years in marine and continental sequences. Paleogeogr., Paleoclimatol., Paleoecol., 16:1-216.

Dalrymple, G. B., Jarrard, R. D., and Claque, D. A., 1975. K-Ar ages of some volcanic rocks from the Cook and Austral islands. Geol. Soc. Am. Bull., 86:1463-1467.

Duncan, R. A., and McDougall, T., 1974. Migration of volcanism with time in the Marquesas Islands, French Polynesia. Earth Planet. Sci. Lett., 21:414-420.

Hardenbol, J., and Berggren, W. A., 1978. A new Paleogene numerical time scale. In Cohee, G. V., Glaessner, M. F., and Hedberg, H. D. (Eds.), Contributions to the Geologic Time Scale: Stud. Geol., (Tulsa, Okla.), no. 6:213-234.

Heezen, B. C., MacGregor, I. D., et al., 1973. Init. Repts. DSDP, 20: Washington (U.S. Govt. Printing Office).

Kennett, J. P., McBirney, A. R., and Thunell, R. C., 1977. Episodes of Cenozoic volcanism in the circum-Pacific region. J. Volcanol. Geotherm. Res., 2:145-163.

Ladd, H. S., Ingerson, E., Townsend, et al., 1953. Drilling on Eniwetok Atoll, Marshall Islands. Am. Assoc. Pet. Geol. Bull., 37: 2257-2280.

Moore, T. C., van Andel, Tj. H., Sancetta, C., et al., 1978. Cenozoic hiatuses in pelagic sediments. Micropaleontology, 24:113-138.

Rea, D. K., and Scheidegger, K. F., 1979. Eastern Pacific spreading rate fluctuation and its relation to Pacific area volcanic episodes. J. Volcanol. Geotherm. Res., 5:135-148.

Schlanger, S. O., Jackson, E. D., et al., 1976. Init. Repts. DSDP, 33: Washington (U.S. Govt. Printing Office).

Sclater, J. G., Abbot, D., and Thiede, J., 1977. Paleobathymetry and sediments of the Indian Ocean. In Heirtzler, J. R., Bolli, H. M., Davies, T. A., et al. (Eds.), Indian Ocean Geology and Biostratigraphy: Washington (American Geophysical Union), pp. 25-59.

Thiede, J., Vallier, T. L., et al., in preparation. Init. Repts. DSDP, 62: Washington. (U.S. Govt. Printing Office).

Vail, P. R., Mitchum, R. M., Jr., and Thompson, S., III, 1977. Seismic stratigraphy and global changes of sea level, Part 4: Global cycles of relative changes of sea level. In Payton, C. E. (Ed.), Seismic Stratigraphy-Application to Hydrocarbon Exploration: Mem-Am. Assoc. Pet. Geol., 26:63-97.

van Andel, Tj. H., 1975. Mesozoic/Cenozoic calcite compensation depth and the global distribution of calcareous sediments. Earth Planet. Sci. Lett., 26:187-194.

van Andel, T. H., Heath, G. R., and Moore, T. C., Jr., 1975. Cenozoic History and Paleoceanography of the Central Equatorial Pacific Ocean. Mem.-Geol. Soc. Am., 143.

van Hinte, J. E., 1976. A Cretaceous time scale. Am. Assoc. Pet. Geol. Bull., 60:498-516.

Winterer, E. L., Ewing, J. I., et al., 1973. Init. Repts. DSDP, 17: Washington (U.S. Govt. Printing Office).

Winterer, E. L., Riedel, W. R., et al., 1971. Init. Repts. DSDP, 7: Washington (U.S. Govt. Printing Office). 